\title{
Identity, Memory and Legacy: Indigenous Taiwan
}

Sixteen Indigenous peoples/nations have been officially recognized by Taiwan's government: Amis (Pangcah), Atayal, Paiwan, Bunun, Puyuma, Rukai, Tsou, Saisiyat, Yami (Tao), Thao, Kavalan, Truku, Sakizaya, Seediq, Kla'alua and Kanakanavu. Additionally, some ten nations of the plains Indigenous peoples (such as Siraya, and Makatao) are obtaining recognition for their lost Indigenous status since the work of Transitional Justice initiated by President Tsai Ingwen. Unlike the later migrants who came from southeastern China, Taiwan's Indigenous peoples belong to the larger Austronesian grouping of peoples who have spread across all of the Pacific Ocean, to Southeast Asia and across the Indian Ocean to Madagascar. According to official records, the Indigenous population of Taiwan is close to 560,000, constituting 2.24 per cent of the island's total population.

Over past centuries, like other Indigenous populations around the world, Taiwan's Indigenous peoples have faced the disruption to their communities, territories, cultures, languages and traditional values. Since the early seventeenth century, foreign colonizers, including the Netherlands, Spain, the family of Zheng Chenggong, the Manchu Empire, Japan and the Chinese Nationalists under Chiang Kai-shek and Chiang Ching-kuo, have subjugated and oppressed Taiwan's Indigenous peoples (Hsieh, 2006, 2017).

When the Dutch colonized Taiwan in the 17th century, their missionaries began a project of educating, and thus acculturating and assimilating the Indigenous peoples, who were oral tradition based, by teaching a small group to read and write in local Sirayan language. The model of a 'modern

Jolan Hsieh (Siraya Nation) is a Professor and Director of Department of Ethnic Relations and Cultures / Center for International Indigenous Affairs, National Dong Hwa University (Taiwan).

Sifo Lakaw (Pangcah / Amis Nation) is a doctoral student in the Department of Ethnic Relations and Cultures, National Dong Hwa University (Taiwan), and also CEO of Hualien County Tribal College. 
public education' was launched in the 20th Century after the Japanese occupied Taiwan and opened what were called 'Indigenous children education centers'. The teachers were policemen from local stations, and these schools mainly taught Japanese language and rituals in a highly authoritarian education field as part of the colonial government's assimilation agenda. In this way, and many others, Indigenous peoples were deprived of their rights to their own cultures, as Japanese culture was deemed of highest rank.

After World War II, the Republic of China took over Taiwan, Mandarin Chinese substituted Japanese as the national official language, and schools became the sites where Chinese nationalist agendas were pursued. The aim of Indigenous education then was again assimilation of the Indigenous people into a nationalist culture. Prohibiting Indigenous people from speaking their languages in school and public places, along with banning cultural practices, served further to deny the distinctive identities of Taiwan's Indigenous peoples. This history of assimilation policies and educational practices was detrimental to the dignity and cultural values of Indigenous nations. It stigmatized Taiwanese Indigenous languages and cultures both inside the home and in local communities.

Since 1948, human rights have become a hallmark of international law and are often claimed as an attribute of democratic political orders. Rapid economic development in Taiwan during the 1970s and 1980s brought political and social changes to the country as a whole and to its Indigenous peoples. Taiwan, indeed, links human rights with democracy in its standard of world-class democratic society. Among the various rights movements across different times in Taiwan, however, Indigenous peoples' rights often are obscured. (Hsieh, 2014)

Indigenous dance and music in Taiwan is highly diverse. Given the influence of policies from different settler regimes at various stages of history and the ongoing presence of other ethnic cultures, contemporary Indigenous dance and music is constantly negotiating and challenging the dichotomy between the traditional and the contemporary. Examining the traditional and contemporary functions of Taiwan's Indigenous dance, music, and media is important, especially following President Tsai Ing-wen's apology on behalf of the government to the country's Indigenous peoples (Hsieh, 2017). For cultural 
(including language, dance, music, and etc) revitalization purposes, Taiwanese Indigenous scholars and activists must utilize these golden opportunities to connect to their cultural traditional and knowledge. Meanwhile, we need also to be rethinking how to apply 'cultural performance' into where we are at now.

In our experience, language revitalization, as facilitated by the performing arts, plays an important role in sustaining Indigenous culture and identity. For example, for the Siraya people, the revitalization and continuation of culture through ritual practice has been impacted by memory re-collecting and identity seeking. Even though the Night Ritual has been recognized by the government as an official ethnic culture legacy, because no one is able to complete the ritual in the Siraya language as tradition deems, much effort has been devoted to language revitalization for younger generations.

How can language, cultural and identity revitalization take place when the 'sacredness' of ritual cannot be performed through 'dance and music' as before? New songs are being composed and practiced with both traditional and contemporary elements by a younger generation. This leads, perhaps inevitably, to debates around the question of 'authenticity'. However, many Indigenous people now take the view that 'the very question of Indigenous authenticity has deep roots in colonial racism' (Sissons, 2005: 43). They instead try to demonstrate that 'authentic' culture is what is lived and performed through the resilience of Indigenous peoples. 


\section{References}

Hsieh, Jolan. Collective Rights of Indigenous Peoples: IdentityBased Movement of Plain Indigenous in Taiwan. 2006. New York: Routledge, 2010.

Hsieh, Jolan. 'Development of Human Rights Consciousness in Taiwan'. Taiwan's Struggle: Voices of the Taiwanese, edited by S. Lee and J. Williams. Plymouth, UK: Rowman \& Littlefield, 2014. 107-120.

Hsieh, Jolan. 'The Changing Identities of Taiwan's Plains Indigenous Peoples'. Changing Taiwanese Identities, edited by B. Jacobs and P. Kang. New York: Routledge, 2017. 1227 ,

Sissons, Jeffrey. First Peoples. Indigenous Peoples and Their Futures. London: Reaktion, 2005.

Jolan Hsieh (Siraya Nation) is a Professor and Director of Department of Ethnic Relations and Cultures / Center for International Indigenous Affairs, National Dong Hwa University (Taiwan).

Sifo Lakaw (Pangcah / Amis Nation) is a doctoral student in the Department of Ethnic Relations and Cultures, National Dong Hwa University (Taiwan), and also CEO of Hualien County Tribal College. 